\title{
Penentuan Resistivity Tanah Di Dalam Menetapkan Area Pemasangan Grounding Gardu Distribusi 20 Kv Mengunakan Kombinasi Grid dan Rod di Kampus Politeknik Negeri Padang
}

\author{
Eart Resistivity Clasification In To Determinite Grounding Distribution \\ House Area In $20 \mathrm{Kv}$ Using Grid And Rod Combination In Politeknik State \\ Padang
}

\author{
Junaidi Asrul, Wiwik Wiharti, Efendi \& Firmansyah
}

Jurusan Teknik Elektro Politeknik Negeri Padang Kampus Limau Manis Padang 25163

Telp.0751-72590 Fax.0751-72576 Email: junaidi_8189@yahoo.co.id

\begin{abstract}
To obtain a small earth (near zero) resistivity value is determined by the number of planted electrodes and soil type properties. Difficulty in obtaining this small resistivity value often errors in estimating soil properties or soil type resistance so that failure to obtain soil barriers often occurs.

To determine the desired amount of material can be measured soil type resistor value, by measuring the soil resistivity value so that the estimated material cost estimation can be achieved well. then in this research using geoelectric method with Schlumberger configuration. Schlumberger method is a method with a constant system of spacing rules with the note of the ' $n$ ' multiplier is the comparison of the distance between the C1-P1 or (C2$P 2)$ electrodes with P1-P2. The instrument used is a resistivity meter ( Naniura) equipped with four electrodes which have the ability to read output voltage response due to current injected into the ground surface through two current electrodes and two potential electrodes. In this study used progress to map the $2 D$ isoresistivity beneath the measured surface. .

The results of this soil resistivity measurement can be determined with certainty the amount of material used and the cost of workmanship provided to establish the proper grounding system to be attached to a $20 \mathrm{kV}$ Distribution substation at the State Polytechnic Padang State Electricity Laboratory. So that the grounding system in pairs meet the standards that have been determined and can be categorized both and safe for humans and equipment for grounding Distribution Distributors $20 \mathrm{kV}$ Electricity Engineering Laboratory at the State Polytechnic Campus Padang
\end{abstract}

Keywords : Resistivity, Geolistrik

\section{PENDAHULUAN}

Menjadi hal penting sekali sistem grounding pada gardu induk diperhatikan, karena pada Gardu Distribusi $20 \mathrm{kV}$ sangat dibutuhkan sistem grounding yang layak dan sangat handal, hal ini diperlukan karena apabila terjadi gangguan pada fasa ke tanah ini akan membahayakan keselamatan manusia dan sistem kelistrikan yang ada, karena apabila ada arus gangguan mengalir pada bagian peralatan ke tanah, ini bisa menimbulkan gradien tegangan pada permukaan tanah yang bisa membahayakan manusia dan peralatan yang ada di sekitar area gardu induk tersebut.

Sistem Grounding peralatan gardu induk yang umum digunakan saat ini adalah sistem grounding Rod, menggunakan kisi Grid dan gabungan antara sistem grounding Grid dan Rod. Dari ketiga model sistem grounding ini sistem kisi Grid dan Rod paling sering digunakan untuk Gardu Induk Tegangan Menengah $20 \mathrm{kV}$. Namun dari pada itu seringnya kegagalan dalam pemasangan sistim grounding pada gardu distribusi untuk mendekati nilai resistivity tanah yang kecil dari $0,5 \mathrm{Ohm}$ oleh karena itu 
sangatlah penting untuk mengetahui karakteristik dari tanah yang ada di kampus Politeknik Negeri padang.

Pentingnya kita mengetahui Sifat geologi tanah karena geologi tanah merupakan faktor utama yang menentukan resistivity jenis tanah. Bahan dasar dari pada tanah relatif bersifat bukan penghantar. Tanah liat umumnya mempunyai tahanan jenis terendah, sedang batu-batuan dan quartz bersifat sebagai insulator. Untuk mengetahui nilai resistivity tanah sangat tepat diterapkan metode geolistrik untuk melihat karakteristik tanah dan besar nilai resistivity tanah yang ada di area yang akan di pasang sistem grounding pada gardu distribusi $20 \mathrm{kV}$. Dengan mengetahui nilai resistivity tanah tersebut, maka dapat menentukan sistem grounding yang tepat untuk digunakan pada gardu distribusi sesuai dengan kondisi karakteristik tanah di area tersebut. Sehingga sistem grounding yang di pasang memenuhi standard yang telah ditentukan dan dapat dikategorikan baik dan aman bagi manusia dan peralatan untuk pentanahaa Gardu Distribusi $20 \mathrm{kV}$ Labor Teknik Listrik di Kampus Politeknik Negeri Padang.

Maka dalam penelitian ini akan dilakukan pengukuran dan perhitungan untuk menganalisis nilai dari resistivity pentanahan, dengan menerapkan metoda geolistrik yang merupakan acuan sebelum memasang sistem grounding yang tepat pada gardu distribusi $20 \mathrm{kV}$ Labor Teknik Listrik di Kampus Politeknik Negeri Padang maupun pemasangan-pemasangan sistem grounding di manapun, karena dengan metode geolistrik sangat efektif dalam meningkatkan kualitas dari sistem grounding yang akan digunakan.

Berdasarkan latar belakang diatas maka tujuan dari penelitian ini adalah :

1. Melakukan pengukuran resistivity jenis tanah dengan sistem geolistrik di kampus Politeknik Negeri padang.
2. Menghitung dan Menganalisa hasil nilai pengukuran resistivity jenis tanah dalam menentukan metoda yang cocok untuk pemasangan sistem grounding pada gardu distribusi $20 \mathrm{kV}$ di kampus Politeknik Negeri padang baik dengan metoda Grid, Rod atau dengan metoda kombinasi Grid dan Rod.

3. Menentukan metoda sistem grounding pada Gardu distribusi pada kampus Politeknik Negeri Padang.

Berdasarkan dari latar belakang diatas maka dapat kita rumuskan permasalah yang akan dibahas dalam penelitian ini yaitu :

1. Bagaimana menentukan metode pengukuran nilai resistivity jenis tanah untuk grounding pada Gardu distribusi $20 \mathrm{kV}$ Labor Teknik Listrik di kampus Politeknik Negeri Padang.

2. Bagaimana menghitung dan menganalisa nilai resistivity tanah dengan menggunakan software progress.

3. Bagaimana menganalisa pengaruh resistivity jenis tanah terhadap nilai tahanan pengetanahan dari sistem Grounding pada gardu distribusi dengan tipe kombinasi grid dan Rod di kampus Politeknik Negeri padang.

Umum Sistem pentanahan/ grounding system adalah suatu rangkaian/jaringan mulai dari kutub pentanahan/elektroda, hantaran penghubung sampai terminal pentanahan yang berfungsi untuk menyalurkan arus lebih ke bumi, agar perangkat peralatan dapat terhindar dari pengaruh petir dan tegangan asing lainnya.

\section{Tahanan Jenis Tanah}

Tahanan jenis tanah adalah tahanan listrik dari tahanan tanah yang berbentuk kubus dengan volume 1 meter kubik. 
Kadang- kadang tahanan jenis dinyatakan dalam ohm- m. Pernyataan ohm-m merepresentasikan tahanan diantara dua permukaan yang berlawanan dari suatu volume yang berisi 1 meter sampai 3 meter. Untuk mendapatkan tahanan pentanahan yang kecil diperlukan upaya sebagai berikut, mengetahui tahanan jenis tanah, kemudian membuat bentuk kutub tanah yang sesuai.

\section{Sifat geologi tanah}

Ini merupakan faktor utama yang menentukan tahanan jenis tanah. Bahan dasar dari pada tanah relatif bersifat bukan penghantar. Tanah liat umumnya mempunyai tahanan jenis terendah, sedang batu-batuan dan quartz bersifat sebagai insulator.

Tabel 1. dibawah ini menunjukkan harga-harga ( $\rho$ ) dari berbagai jenis tanah.

\begin{tabular}{|c|l|c|}
\hline No. & \multicolumn{1}{|c|}{ Jenis Tanah } & $\begin{array}{c}\text { Tahanan } \\
\text { Jenis Tanah } \\
\text { (ohm.meter) }\end{array}$ \\
\hline 1. & $\begin{array}{l}\text { Tanah yang } \\
\text { mengandung air }\end{array}$ & $5-6$ \\
& garam & \\
2. & Rawa & 30 \\
3. & Tanah liat & 100 \\
4. & Pasir Basah & 200 \\
5. & Batu-batu kerikil & 500 \\
6. & basah & 1000 \\
7. & Pasir dan batu krikil & 3000 \\
& kering & Batu \\
\hline
\end{tabular}

\section{Pentanahan Rod}

Pada pentanahan rod ini, batangbatang elektroda ditanam tegak lurus dengan permukaan tanah. Bila elektroda rod tersebut dialiri arus gangguan ke tanah ketika daerah perumahan terjadi gangguan tanah, maka arus tersebut akan menyebar atau mengalir ke tanah dan akan mengakibatkan naiknya beda potensial pada permukaan tanah. Makin jauh dari elektroda tersebut, penyebaran arus semakin luas, sehingga kepadatan arusnya juga semakin berkurang.

\section{a. Satu Batang Elektroda yang ditanam Tegak Lurus ke dalam Tanah}

Pada Gambar 1. Dibawah ini menunjukkan satu batang elektroda berbentuk silinder dengan panjang $\mathrm{L}$ yang di tanam tegak lurus permukaan tanah berdiameter $2 \mathrm{a}$, dengan bayangan di atas permukaan tanah. Elektroda tersebut ditanam dengan berbagai jenis kedalaman.

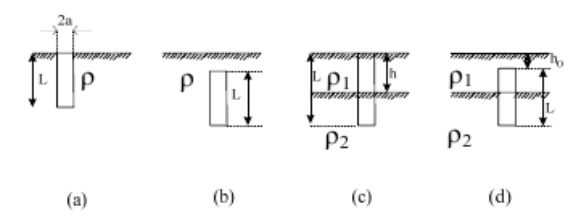

Gambar 1. Penanaman elektroda batang (rod)

Untuk elektroda yang ditanam tegak lurus dekat permukaan tanah (Gambar. 1), nilai tahanannya yaitu :

$$
\mathrm{R}=\frac{\rho_{1}}{2 \cdot \pi \cdot \mathrm{L}}\left(\ln \frac{4 \mathrm{~L}}{\mathrm{a}}-1\right)
$$

Untuk elektroda yang ditanam tegak lurus pada kedalaman beberapa $\mathrm{cm}$ dari permukaan tanah (Gambar.1b), nilai tahanannya yaitu :

$$
\mathrm{R}=\frac{\rho_{1}}{2 . \pi \cdot \mathrm{L}}\left(\ln \frac{2 \mathrm{~L}}{\mathrm{a}}-1\right)
$$

Untuk elektroda yang ditanam tegak lurus dekat permukaan tanah dan menembus lapisan tanah kedua (Gambar.1c), nilai tahanannya yaitu :

$$
\mathrm{R}=\frac{\rho_{2}}{2 . \pi \cdot \mathrm{L}}\left(\ln \frac{4 \mathrm{~L}}{\mathrm{a}}-1\right)
$$

Untuk elektroda yang ditanam tegak lurus pada kedalaman beberapa $\mathrm{cm}$ dari permukaan tanah dan menembus lapisan tanah kedua (Gambar.1d), nilai tahanannya yaitu : 


$$
\begin{aligned}
& \mathrm{R}=\frac{\rho_{2}}{2 \pi\left(\mathrm{h}-\mathrm{h}_{0}\right)}\left(\ln \frac{2 \mathrm{~L}}{\mathrm{a}}-1+\frac{\ln 2}{\left.1+\frac{(4 \ln 2) \mathrm{h}_{0}}{\mathrm{~L}}\right)+\frac{\rho_{1}}{\mathrm{~h}} \varphi_{0}}\right. \\
& \phi_{\mathrm{o}}=\frac{\frac{1}{2 \pi}\left(\ln \frac{1}{1-\mathrm{K}}\right)}{\sqrt{\left(\frac{\mathrm{N}}{\mathrm{F}_{\mathrm{o}}}-1\right)^{2}+1}} \\
& \mathrm{~F}_{\mathrm{o}}=\cdot \frac{\mathrm{L}}{1-\mathrm{O}, 9 \mathrm{~K}} \\
& \mathrm{~K}=\cdot \frac{\rho_{2}-\rho_{1}}{\rho_{2}+\rho_{1}}
\end{aligned}
$$

dengan :

$\mathrm{R}=$ Tahanan dari satu batang elektroda $(\Omega)$

$\mathrm{L} \quad=$ Panjang batang elektroda dalam tanah (m)

$\mathrm{a} \quad=$ Jari-jari batang elektroda (m)

p1 = Tahanan jenis lapisan tanah pertama ( $\Omega-\mathrm{m})$

ค2 $=$ Tahanan jenis lapisan tanah kedua $(\Omega$ $\mathrm{m})$

rho = Kedalaman penanaman elektroda $(\mathrm{m})$

$\mathrm{K}=$ Faktor refleksi

\section{METODOLOGI}

\section{Pengukuran Nilai Resistivitas Tanah dengan Metode Geolistrik}

Untuk memperoleh resistivity tanah yang rendah dengan hasil kualitas yang baik, maka perlu dilakukan pengukuran dengan metode geolistrik, karena dengan metode geolistrik sangat membantu sekali dalam mengetahui sifat tanah yang ada di sekitar tempat pemasangan sistem grounding pada Gardu Induk distribusi di Kampus Politeknik Negeri padang.

Dalam melakukan pengambilan data dengan metode geolistrik diperlukan peralatan resistivity meter dan beberapa elektroda batang, dan beberapa meter kabel baik untuk elektroda potensial, maupun untuk elektroba Arus. Metoda yang akan diterapkan untuk menggambil data adalah dengan menerapkan metoda Schulemberger yaitu dengan menggunakan 4 (empat) elektroda batang seperti pada gambar dibawah ini.Awalnya pada saat penusulan proposal penelitian ini, metoda yang digunakan adalah metoda wenner, karena melihat tujuan pengukuran dengan mengetahaui lapisan secara vertical, maka metoda yang lebih cocok digunakan adalah dengan metoda schlumberger Metoda Schlumberger mampu mendeteksi variasi lapisan batuan secara vertikal dengan membentangkan 2 buah elektroda arus dan 2 buah elektroda potensial dengan jarak tertentu di tancap ke tanah seperti pada gambar di bawah ini.

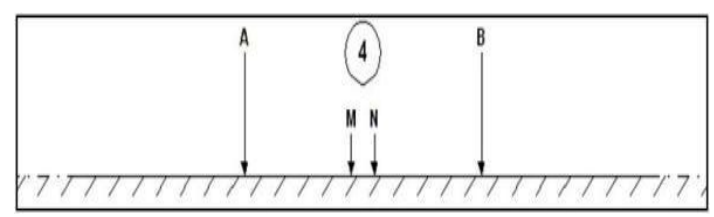

Gambar 2. Rangkaian Schlumberger

- Keunggulan : kemampuan untuk mendeteksi adanya nonhomogenitas lapisan batuan pada permukaan

- Kelemahan : pembacaan tegangan pada elektroda $\mathrm{MN}$ adalah lebih kecil terutama ketika jarak $\mathrm{AB}$ yang relatif jauh.

Dari gambar diatas dapat dilihat bahwa C1 dan C2 merupakan elektroda arus dan P1 dan P2 untuk elektroda potensial, sedangkan $\mathrm{r}$ merupakan jarak antara elektroda arus dengan elektroda potensial. Dari metode schlumberger yang akan diterapkan dalam pengambilan data maka dihitung besar nilai resistivity tanah dengan persamaan dibawah ini yaitu :

$$
\begin{aligned}
& V_{1}=\frac{I \rho}{2 \pi}\left(\frac{1}{r_{1}}-\frac{1}{r_{2}}\right) \\
& V_{2}=\frac{I \rho}{2 \pi}\left(\frac{1}{r_{\mathrm{g}}}-\frac{1}{r_{4}}\right) \\
& \left.\Delta V=V_{1}-V_{2} \ldots 10\right) \\
& \Delta V=\frac{I \rho}{2 \pi}\left(\frac{1}{r_{1}}-\frac{1}{r_{2}}-\frac{1}{r_{\mathrm{g}}}-\frac{1}{r_{4}}\right) \\
& \rho=2 \pi\left(\frac{1}{r_{1}}-\frac{1}{r_{2}}-\frac{1}{r_{\mathrm{g}}}-\frac{1}{r_{4}}\right)^{-1} \frac{\Delta V}{I} . \\
& \rho=K \frac{\Delta V}{I}
\end{aligned}
$$




\section{Pengambilan data}

Penentuan resistivitas tanah di kampus Politeknik Negeri padang

1. Menyusun rangkaian alat resistivitymeter.

2. Mengaktifkan resistivitymeter kemudian menginjeksikan arus listrik ke elektroda dengan kedalaman $30 \mathrm{~cm}$.

3. Melakukan pengukuran pada lintasan kemudian mencatat arus listrik (I) dan beda potensial (V) antara 2 titik elektroda.

4. Mengubah letak elektroda arus dan elektroda potensial sebanyak 10 kali dengan jarak yang telah ditentukan saat pengukuran.

5. Menghitung resistivitas semu hasil pengukuran dengan menggunakan persamaan (13).

Dalam pelaksanaannya, jumlah elektroda yang digunakan sebanyak 4 batang dengan spasi elektroda terkecil adalah $30 \mathrm{~cm}$. Karena jarak antar elektroda menentukan kedalaman jangkauan pengkuran, maka pengukuran dilakukan dengan memvariasikan jarak tersebut dan menggeser posisi keseluruhan konfigurasi elektroda pada lintasan yang dibuat setiap jarak $30 \mathrm{~cm}$ untuk memperoleh informasi mengenai distribusi konduktivitas secara vertikal maupun lateral.

\section{HASIL}

\section{Lokasi Pengukuran}

Penelitian dilaksanakan pada Politeknik Negeri Padang di jurusan Teknik Elektro yaitu di Labor Sistem Distribusi dan proteksi, dan denah pengukuran dilakukan di area Gardu Distribusi $20 \mathrm{KV}$ labor system Distribusi dan proteksi
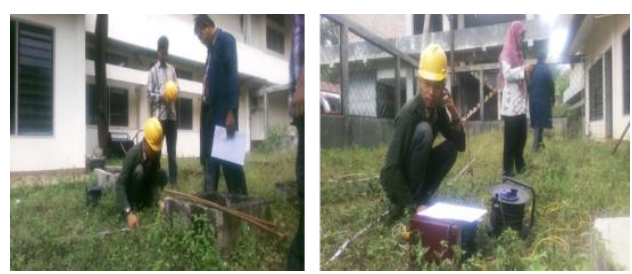

Gambar 2. Lokasi pengukuran dan Proses Pengukuran

\section{Data Pengukuran dan Analisa Data}

A. Hasil Pengukuran Resistivity Tanah dengan Menggunakan Alat Ukur Geolistrik dengan menggunakan metoda Schlumberger

Tabel 2. Hasil Pengukuran Pada Titik 1

\begin{tabular}{|c|c|}
\hline Argh. Bentangan. & - Barat dan timur \\
\hline Metoda & :Schlumberger \\
\hline Lakasi. & : Labor Sistem Distribusi dag Rroteksi \\
\hline CHREA & : Gecah becrouran \\
\hline Kota & Padang \\
\hline
\end{tabular}

\begin{tabular}{|c|c|c|c|c|c|c|}
\hline NO & $\begin{array}{l}M N / 2 \\
\text { (meter) }\end{array}$ & $\begin{array}{c}\mathrm{AB} / 2 \\
\text { (meter) }\end{array}$ & $\mathrm{K}$ & $\begin{array}{c}1 \\
\text { (mA) }\end{array}$ & $\begin{array}{l}v \\
(m-2)\end{array}$ & $\begin{array}{c}R \\
\text { (Phom }\end{array}$ \\
\hline \multirow{8}{*}{1} & 0.5 & 1.5 & 6.29 & 311 & 3471 & 70.20 \\
\hline & 0.5 & 2.5 & 18.86 & 348 & 1713 & 92.79 \\
\hline & 0.5 & 4 & 49.46 & 292 & 698 & 118.20 \\
\hline & 0.5 & 6 & 112.26 & 331 & 373.9 & 98.79 \\
\hline & 0.5 & 8 & 200.18 & 284 & 164.5 & 112,10 \\
\hline & 0.5 & 10 & 313.22 & 252 & 80.6 & 100.23 \\
\hline & 0.5 & 12 & 451.38 & 197 & 38.2 & 85.76 \\
\hline & 0.5 & 15 & 705.72 & 209 & 19.6 & 63.51 \\
\hline \multirow{4}{*}{2} & 5 & 15 & 62.80 & 211 & 240.4 & 71.59 \\
\hline & 5 & 20 & 117.75 & 440 & 172.6 & 45.92 \\
\hline & 5 & 25 & 188.40 & 337 & 60.2 & 33.91 \\
\hline & 5 & 30 & 274.75 & 265 & 27.4 & 27.48 \\
\hline \multirow{5}{*}{3} & 10 & 30 & 125.60 & 267 & 66.9 & 31.40 \\
\hline & 10 & 40 & 235.50 & 245 & 25.1 & 23.55 \\
\hline & 10 & 50 & 376.8 & 334 & 19.8 & 22.61 \\
\hline & 10 & 60 & 549.5 & 230 & 8 & 16.49 \\
\hline & 10 & 75 & 867.45 & 349 & 7.2 & 17.35 \\
\hline \multirow{3}{*}{4} & 25 & 75 & 314 & 352 & 21.3 & 18.84 \\
\hline & 25 & 100 & 588.75 & 280 & 7.9 & 17.66 \\
\hline & 25 & 125 & 942 & 255 & 5.4 & 18.84 \\
\hline
\end{tabular}

B. Analisa Perhitungannya nilai factor geometrinya dengan persamaan sebagai berikut :

1. Untuk Jarak Pengukuran 1,5 Meter untuk elektroda $\mathrm{AB}$ dan jarak 0,5 meter untuk elektroda MN

$K=\pi \cdot\left(\frac{A B^{2}-M N^{2}}{2 \cdot M N}\right)$ 


$$
\begin{aligned}
& K=3,14 \cdot\left(\frac{1,5^{2}-0,5^{2}}{2.0,5}\right) \\
& K=3.14 \cdot\left(\frac{2,25-0,25}{1}\right)
\end{aligned}
$$

2. Untuk Jarak Pengukuran 2,5 Meter untuk elektroda $\mathrm{AB}$ dan jarak 0,5 meter untuk elektroda MN

$$
K=\pi \cdot\left(\frac{A B^{2}-M N^{2}}{2 . M N}\right)
$$

$$
K=3,14 \cdot\left(\frac{2,5^{2}-0,5^{2}}{2.0,5}\right)
$$$$
K=3.14 \cdot\left(\frac{6,25-0,25}{1}\right)
$$$$
K=18,86
$$

3. Untuk Jarak Pengukuran 4 Meter untuk elektroda $\mathrm{AB}$ dan jarak 0,5 meter untuk elektroda MN

$$
\begin{aligned}
& K=\pi \cdot\left(\frac{A B^{2}-M N^{2}}{2 \cdot M N}\right) \\
& K=3,14 \cdot\left(\frac{4^{2}-0,5^{2}}{2 \cdot 0,5}\right) \\
& K=3,14 \cdot\left(\frac{16-0,25}{1}\right) \\
& K=49,46
\end{aligned}
$$

C. Setelah Menghitung nilai factor geometrinya atau nilai (K), maka berdasarkan besar nilai Arus dan Tegangan pada hasil pengukuran di lapangan maka kita bisa menghitung besarnya nilai Resistivity Tanah $(\rho)$ dengan persamaan sebagai berikut :

1. Untuk Jarak Pengukuran 1,5 Meter untuk elektroda $\mathrm{AB}$ dan jarak 0,5 meter untuk elektroda $\mathrm{MN}$ dan nilai $\mathrm{K}=6,28 \quad \mathrm{I}=311 \mathrm{~mA}$ dan $\mathrm{V}=3471$ $\mathrm{mV}$, maka besar nilai resistivity : $\rho_{a}=\left(\frac{\Delta V}{I}\right) x K$

$$
\begin{aligned}
& \rho_{a}=\left(\frac{3471}{311}\right) \times 6,29 \\
& \rho_{a}=70,20 \text { Ohm.M }
\end{aligned}
$$

2. Untuk Jarak Pengukuran 2,5 Meter untuk elektroda $\mathrm{AB}$ dan jarak 0,5 meter untuk elektroda $\mathrm{MN}$ dan nilai $\mathrm{K}=18,85 \mathrm{I}=348 \mathrm{~mA}$ dan $\mathrm{V}=$ $1713 \mathrm{mV}$, maka besar nilai resistivity :

$$
\begin{aligned}
& \rho_{a}=\left(\frac{\Delta V}{I}\right) \times K \\
& \rho_{a}=\left(\frac{1713}{348}\right) \times 18,86 \\
& \rho_{a}=92,79 \text { ohm. M }
\end{aligned}
$$

3. Untuk Jarak Pengukuran 4 Meter untuk elektroda $\mathrm{AB}$ dan jarak 0,5 meter untuk elektroda $\mathrm{MN}$ dan nilai $\mathrm{K}=49,46 \quad \mathrm{I}=292 \mathrm{~mA}$ dan $\mathrm{V}=698$ $\mathrm{mV}$, maka besar nilai resistivity :

$$
\begin{aligned}
& \rho_{a}=\left(\frac{\Delta V}{I}\right) x K \\
& \rho_{a}=\left(\frac{698}{292}\right) \times 49,46 \\
& \rho_{a}=118,2 \text { ohm.M }
\end{aligned}
$$

Setelah melakukan perhitungan dengan persamaan perhitungan nilai tahanan jenis tanah tersebut maka data pengukuran dan perhitungan kita olah dengan menggunakan software proggers untuk melihat kurva kedalam lapisan tanah berdasarkan nilai resistivity dari perhitungan tadi.

\section{Analisa kurva resistivity seperti pada gambar 3 untuk kedalaman sebagai berikut :}

1. Pada kedalaman $0-1$ meter didapatkan tahanan jenis lapisan tanahnya sebesar 57,62 Ohm.m diprediksikan sebagai Top Soil.

2. Pada kedalaman 1-5 meter didapatkan tahanan jenis lapisan tanahnya sebesar 
185,54 Ohm.m diprediksikan sebagai lempung

3. Pada kedalaman 5 -64 meter didapatkan tahanan jenis lapisan tanahnya sebesar $\quad 16,97 \quad$ Ohm.m diprediksikan sebagai Batuan lempung dan serpihan.

4. Pada kedalaman $64 \quad-98$ meter didapatkan tahanan jenis lapisan tanahnya sebesar $\quad 13,39$ Ohm.m diprediksikan sebagai lempung.

5. Pada kedalaman 98-140 meter didapatkan tahanan jenis lapisan tanahnya sebesar 37,48 Ohm.m diprediksikan sebagai batuan lempung.

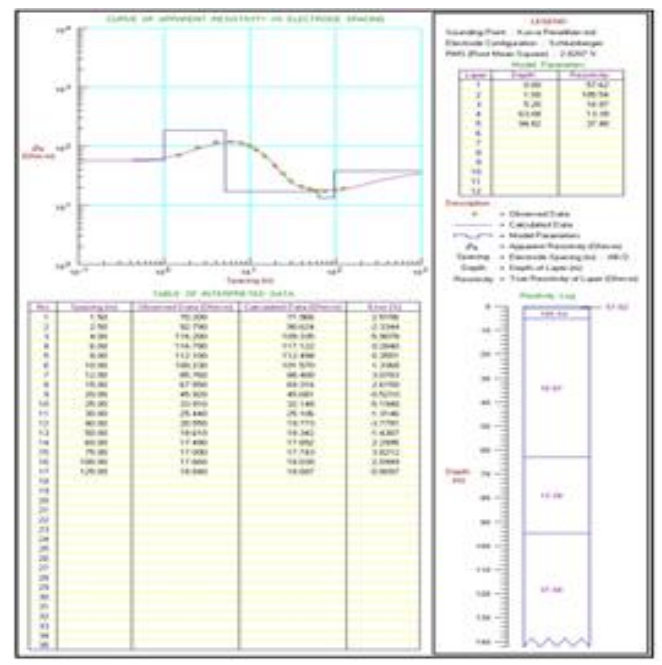

Gambar 3. Kurva Pengukuran resistivity Tanah Pada titik 1

D. Hasil Pengukuran Resistivity Tanah dengan Menggunakan Alat Ukur Geolistrik dengan menggunakan metoda Schlumberger Pada Titik Pengukuran Kedua
Tabel 3. Hasil Pengukuran Pada Titik 2

\begin{tabular}{|c|c|c|c|c|c|c|}
\hline \multicolumn{3}{|c|}{ No. Titik } & \multicolumn{4}{|l|}{ : Titik 2} \\
\hline \multicolumn{3}{|c|}{ Arah Bentangan } & \multicolumn{4}{|c|}{ Barat dan timur } \\
\hline \multicolumn{3}{|c|}{ Metoda } & \multicolumn{4}{|c|}{ Schlumberger } \\
\hline \multicolumn{3}{|c|}{ Lokasi } & \multicolumn{4}{|c|}{ : Labor Sistem Distribusi dan Proteksi. } \\
\hline \multicolumn{3}{|c|}{ Cuaca } & \multicolumn{4}{|c|}{ : Cerab } \\
\hline \multicolumn{3}{|c|}{ Kota } & \multicolumn{4}{|l|}{ :Padang } \\
\hline \multirow{2}{*}{ NO } & $\mathrm{MN} / 2$ & & \multirow{2}{*}{$\mathrm{k}$} & 1 & & R \\
\hline & (meter) & (meter) & & $(\mathrm{mA})$ & $(m, v)$ & (Ohm.M \\
\hline \multirow{8}{*}{1} & 0.5 & 1.5 & 6.29 & 70 & 369.5 & 33.149 \\
\hline & 0.5 & 2.5 & 18.85 & 63 & 88 & 26.330 \\
\hline & 0.5 & 4 & 49.48 & 62 & 21.46 & 17.078 \\
\hline & 0.5 & 6 & 112.31 & 50 & 7.4 & 16.621 \\
\hline & 0.5 & 8 & 200.28 & 58 & 5 & 17.265 \\
\hline & 0.5 & 10 & 313.37 & 168 & 7.4 & 13.803 \\
\hline & 0.5 & 12 & 451.60 & 175 & 5.2 & 6.84 \\
\hline & 0.5 & 15 & 706.07 & 196 & 1.9 & 17.80 \\
\hline \multirow{4}{*}{2} & 5 & 15 & 62.80 & 198 & 56.1 & 7.688 \\
\hline & 5 & 20 & 117.75 & 98 & 10.3 & 12.38 \\
\hline & 5 & 25 & 188.40 & 148 & 8 & 10.39 \\
\hline & 5 & 30 & 274.75 & 52 & 1.3 & 6.87 \\
\hline \multirow{5}{*}{3} & 5 & 30 & 125.60 & 52 & 1.3 & 6.87 \\
\hline & 5 & 40 & 235.50 & 380 & 7 & 9.114 \\
\hline & 10 & 50 & 376.8 & 211 & 10.1 & 18.045 \\
\hline & 5 & 75 & 1759.29 & 292 & 2.7 & 16.267 \\
\hline & 10 & 75 & 867.45 & 293 & 7.4 & 21.918 \\
\hline \multirow{3}{*}{4} & 10 & 100 & 1555.09 & 169 & 1.8 & 16.563 \\
\hline & 10 & 125 & 2438.66 & 275 & 1.9 & 16.848 \\
\hline & 25 & 125 & 942 & 217 & 6.8 & 29.533 \\
\hline
\end{tabular}

Dengan cara menghitung Nilai Faktor geometrid an nilai resistivity Tanahnya sama dengan cara analasisa pengukuran pertama, setelah data pengukuran di analisa dengan Software Progress maka di dapatkan hasil nya sebagia berikut :

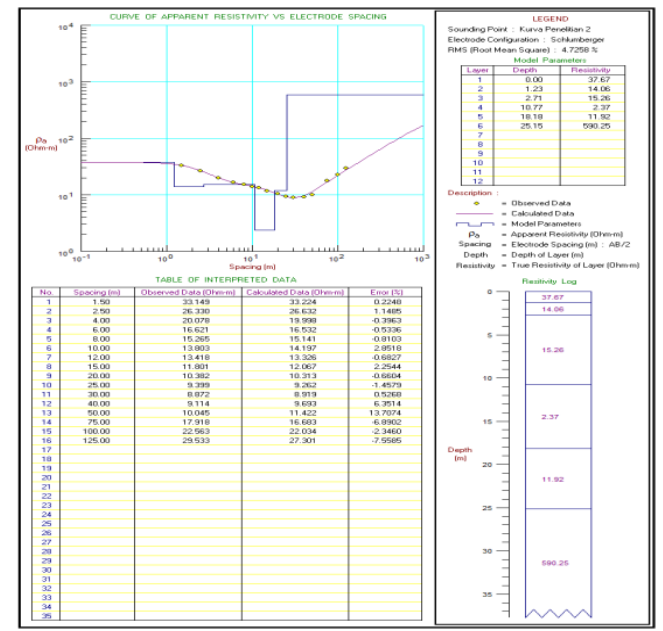

Gambar 4. Kurva Pengukuran resistivity Tanah Pada Titik 2

Dari hasil kurva tersebut di simpulkan bahwa lapisan tanah di labor system proteksi dan system distribusi masih diasumsikan lapisan tanah Lempung. 
Setelah mengetahui lapisan tanah yang terdapat pada area gardu distribusi 20 KV di Labor Sistem Distribusi dan proteksi, maka kita bisa merancang dan menerapkan jenis metoda pentanahan yang digunakan pada Gardu distribusi tersebut sehingga mendapatkan system pentanahan yang lebih baik.

Pada kedalaman 1-6 meter bahwa terdapat lapisan tanah lempung, pasir, kerikil kering jadi dalam kondisi tersebut diprediksi ada mengandung kelembaban air dengan jumlah yang sedikit, inilah menjadi catatan dalam menentukan metoda pemasangan pentanahan nantinya.

\section{E. Pengukuran dengan mengunakan Metoda Kombinasi Grid dan Rod}

Setelah melakukan pengukuran dan menganalisa hasil pengukuran dengan menggunakan alat ukur Geolistrik dan menganalisa dengan menggunakan software Proggres maka kita bias melihat kondisi tanah yang ada pada area labor system proteksi dan system distribusi yaitu terdapat lapisan lembung, jadi kita bisa menerapkan system grounding dengan menggunakan metoda kombinasi grid dan rod karena hasilnya lebih akurat untuk mendapat nilai tahanan tanah yang $\leq 5 \mathrm{Ohm}$. Sehingga lebih aman dalam mengamankan peralatan system gardu distribusi $20 \mathrm{KV}$ di labor system proteksi dan system distribusi.

Tabel 4. Data pengukuran dan hasil

\begin{tabular}{|c|c|cc|} 
perhitungan \\
\hline No. & $\begin{array}{c}\text { Jumlah } \\
\text { Elektroda }\end{array}$ & $\begin{array}{c}\text { Tahanan } \\
(\text { ohm }) \\
\text { Hasil } \\
\text { pengukuran }\end{array}$ & $\begin{array}{c}\text { Tahanan } \\
(\text { ohm })\end{array}$ \\
$\begin{array}{c}\text { Hasil } \\
\text { perhitungan }\end{array}$ \\
\hline 1. & 1 elektroda & 4 & 4,03 \\
2. & 2 elektroda & 3.8 & 3,93 \\
3. & 4 elektroda & 3.75 & 3,8 \\
4. & 8 elektroda & 3.7 & 3,7 \\
5. & 9 elektroda & 3.5 & 3,65 \\
6. & 10 elektroda & 3.4 & 3,62 \\
7. & 12 elektroda & 3.39 & 3,54 \\
\hline
\end{tabular}

Dari hasil pengukuran semakin banyak kombinasi elektroda yang ditanam, maka semakin kecil nilai tahanan yang didapatkan, dimana resistansi yang diukur berbanding terbalik dengan jumlah elektrodanya.

Nilai hasil pengukuran tersebut dapat digunakan sebagai referensi untuk menentukan jumlah elektroda yang dipasang agar diperoleh nilai Tahanan pentanahan yang kecil yaitu sebasar $\leq 5$ Ohm. Proses Pengukuran Sistem Pentanahan dengan metoda kombinas Grid dan Rod di Labor Sistem Proteski dan Sistem Distribusi program Studi Teknik Listrik
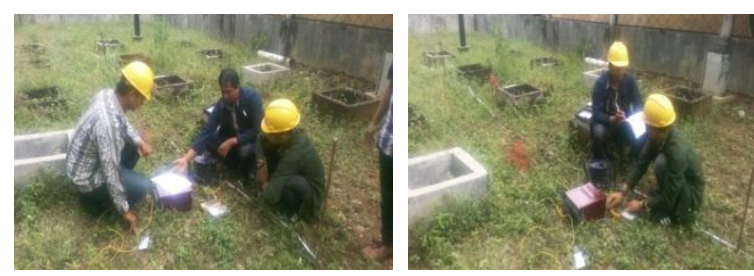

Gambar 5. Pengukuran dengan mengunakan Metoda Kombinasi Grid dan Rod

\section{PEMBAHASAN}

\section{Analisis Data dengan Metoda Kombinasi Grid dan Rod}

Berdasarkan hasil percobaan, didapatkan data seperti yang terdapat pada table pengamatan di atas. Namun jika tahanan dihitung dengan persamaan yang ada, maka didapatkan data sebagai berikut: Kedalaman pemasangan grid:

$$
\begin{aligned}
h^{\prime} & =\sqrt{h x d 1} \\
h^{\prime} & =0.0578
\end{aligned}
$$

Pengetanahan grid:

$$
\begin{aligned}
R 1 & =\frac{\rho g}{\pi L}\left(\ln \frac{2 L}{h^{\prime}}+K 1 \frac{L}{\sqrt{A}}-K 2\right) \\
R 1 & =\frac{62.8}{3.14 x 76}\left(\ln \frac{2 x 76}{0.0578}+1.37\left(\frac{76}{\sqrt{60}}\right)-5.7\right) \\
\mathrm{R} 1 & =4.10 \mathrm{ohm}
\end{aligned}
$$

Hasil pengetanahan grid dan rod: 


$$
\begin{aligned}
& R 12=\frac{\rho p}{\pi L}\left(\ln \frac{2 L}{l}+K 1\left(\frac{L}{\sqrt{A}}\right)-K 2+1\right) \\
& R 12=\frac{50.24}{3.14 x 76}\left(\ln \frac{2 x 76}{1.8}+1.37\left(\frac{76}{\sqrt{60}}\right)-5.7+1\right) \\
& \mathrm{R} 12=2.77 \mathrm{ohm}
\end{aligned}
$$

Tahanan pengentanahan:

$$
R g=\frac{R 1 x R 2-R 12^{2}}{R 1+R 2-2 R 12}
$$

a. Tahanan pengetanahan kombinasi dengan 1 batang rod $(n=1)$ :

$$
\begin{array}{r}
R 2=\frac{\rho p}{2 \pi n l}\left(\ln \frac{8 l}{d 2}-1+2 K 1\left(\frac{l}{\sqrt{A}}\right)(\sqrt{n}-1)^{2}\right) \\
\mathbb{R} 2=\frac{b U .24}{2 \times 3.14 \times 1 \times 1.8}\left(\ln \frac{6 \times 1 . \% 6}{7.98 \times 10^{-x}}-1+2 \times 1.37\left(\frac{1.6}{\sqrt{60}}\right)(\sqrt{1}-1)^{2}\right)
\end{array}
$$

$\mathrm{R} 2=28.85 \mathrm{ohm}$

Jadi:

$$
\begin{aligned}
& R g=\frac{R 1 \times R 2-R 12^{2}}{R 1+R 2-2 R 12} \\
& R g=\frac{4.1 \times 28.85-2.77^{2}}{4.1+28.85-2 \times 2.77} \\
& \operatorname{Rg}=4.03 \mathrm{ohm}
\end{aligned}
$$

Sampai perhitungan dilakukan dengan menggunakan 12 batang elektroda seperti hasil pada table 1 diatas.

Dari data yang didapatkkan berdasarkan perhitungan tersebut tampak bahwa hasil dari perhitungan dan pengukuran terhadap tahanan tanah memiliki nilai yang mendekati sama. Selain itu konfigurasi pentanahan lebih baik yaitu menggunakan konfigurasi segi empat terisi, sebab nilai tahanan yang dihasilkan semakin kecil. Dengan demikian jika terjadi gangguan, arus akan dialirkan ke tanah terlebih dahulu, sehingga dapat menghindari manusia terkena arus gangguan tersebut.

Berdasarkan persamaan tersebut juga dapat disimpulkan bahwa untuk mendapatkan harga tahanan yang lebih kecil dapat dilakukan dengan cara:

a. Memperdalam penanaman elektroda

b. Memperbanyak penanaman elektroda

c. Memperbesar jarak antar masingmasing elektroda

d. Memakai elektroda dengan luas penampang yang lebih besar.

\section{SIMPULAN}

Dari hasil pembahasan dapat disimpulkan sebagai berikut.

1. Untuk memilih lokasi pemasangan grounding, untuk mendapatkan nilai yang kecil diperlukan pengukuran jenis lapisan tanah menggunakan geolistrik.

2. Dari hasil pengukuran yang diperoleh dari 2 titik dengan bentangan 250 meter diperoleh hasil resistivity tanahnya yaitu sifat tanah lempung.

3. Pengukuran dilakukan di 2 lokasi dengan titik yang berbeda dalam satu area yang sama, diperoleh sifat tanah lempung.

4. Area gardu distribusi politeknik negeri padang yang kategorikan sebagai tanah lempung, cocok untuk digunakan metoda grid dan rod.

\section{SARAN}

Untuk memastikan jumlah elektroda yang akan dipasang pasa suatu gardu distribusi, terlebih dahulu dilakukan pengukuran dan jumlah elektroda yang dipasang agar dapat mengestimasi biaya pemasangan pengerjaanya.

\section{DAFTAR PUSTAKA}

[1] Hutauruk, TS. (1991). "Pengetanahan Netral sistem tenaga dan Pengetanahan peralatan", Jakarta:Erlangga. . (1983). "IEEE Guide for measuring earth resistivity, ground Impedance and earth surface potensial of grounding system", IEEEstd 81. 
[3] $\longrightarrow$ SPLN 04-0225. (2000). “

Peraturan Umum umtuk elektroda bumi dan penghantar bumi", PT.PLN ( Persero )

[4] Zulfikar Limolang (2012)."Studi Pengaruh Jenis Tanah Dan Kedalaman Pembumian Driven Rod Terhadap Resistansi Jenis Tanah" .Vol 7, Nomor 14, Oktober 2012

[5] Suryono, (2013).'Evaluasi Tahanan Pentanahan Kawat Netral Pada Jaringan Tegangan Menengah Daerah Perbukitan dan Pantai di Area Pelayanan Jaringan Semarang". ISSN : 2252-4908 Vol. 2 No. 1 April 2013

[6] Anonim, (2004). "Pelatihan Geolistrik Metode Vertical Electrical Sounding (VES)". Lab. Listrik Dasar \& Proyek SEMI QUE - V, Jurusan Elektro FTUNRAM

[7] Azhar dan Gunawan Handayani, (2004). "Penerapan Metode Geolistrik Konfigurasi Schlumberger untuk Penentuan Tahanan Jenis Batubara", Jurusan Geofísika Terapan ITB, Bandung 